\title{
Variability in phytoplankton pigment biomass and taxonomic composition over tidal cycles in a salt marsh estuary
}

\author{
Michael S. Wetz ${ }^{1,6, *}$, Kenneth C. Hayes ${ }^{2}$, Alan J. Lewitus ${ }^{2,3}$, Jennifer L. Wolny ${ }^{4}$, \\ David L. White ${ }^{5}$ \\ ${ }^{1}$ College of Oceanic and Atmospheric Sciences, Oregon State University, 104 COAS Administration Building, Corvallis, \\ Oregon 97331, USA \\ ${ }^{2}$ Belle W. Baruch Institute for Marine and Coastal Sciences, University of South Carolina, PO Box 1630, Georgetown, \\ South Carolina 29442, USA \\ ${ }^{3}$ South Carolina Department of Natural Resources, Marine Resources Research Institute, Hollings Marine Laboratory, \\ 331 Fort Johnson Road, Charleston, South Carolina 29412, USA \\ ${ }^{4}$ Florida Institute of Oceanography, Fish and Wildlife Research Institute, 100 Eighth Avenue SE, St. Petersburg, \\ Florida 33701, USA \\ ${ }^{5}$ NOAA, Hollings Marine Laboratory, 331 Fort Johnson Road, Charleston, South Carolina 29412, USA \\ ${ }^{6}$ Present address: Institute of Marine Sciences, The University of North Carolina-Chapel Hill, 3431 Arendell Street, \\ Morehead City, North Carolina 28557, USA
}

\begin{abstract}
Tidal flow causes high temporal variability in environmental properties that impact ecosystem dynamics. Microbes such as phytoplankton are especially susceptible to tidal advection and mixing, and understanding their role in estuarine food webs and biogeochemical cycles requires information on their biomass and taxonomic composition over short time scales (e.g. tidal cycles). We conducted a survey of phytoplankton pigment biomass and taxonomic composition over complete tidal cycles in 2 salt marsh creeks on 5 sampling occasions from July to September 2000, and assessed environmental factors regulating phytoplankton properties. Tidal input of low chl a water combined with phytoplankton losses (microzooplankton grazing, oyster grazing, settling) caused large decreases in phytoplankton biomass (by 47 to $51 \%$ on average) on the flood tide, and also influenced the taxonomic composition. Depending on sampling date, pennate diatoms or flagellates were primarily reduced on the flood tide. One sampling date followed a heavy rain event, and was marked by substantial increases in tidal creek nutrient concentrations and reduced microzooplankton grazing rates, emphasizing the need to consider the combined influences of nutrients and grazing in explaining bloom formation following rain events. The high tidal variability in phytoplankton properties suggests that strict attention to tidal phase is needed in determining long-term trends or inter-estuary comparisons in phytoplankton biomass, and primary production in tidally-driven estuaries.
\end{abstract}

KEY WORDS: Phytoplankton $\cdot$ Estuaries $\cdot$ Tidal cycles $\cdot$ Grazing $\cdot$ Diatoms $\cdot$ Storms

\section{INTRODUCTION}

Shallow tidal estuaries are dynamic ecosystems, subject to periods of intense wind-driven advection and to tidally induced changes in water column depth over short time scales (hours to $<1 \mathrm{~d}$ ). Phytoplankton and benthic microalgae, important contributors to estuar- ine primary production and food webs (Miller et al. 1996, Underwood \& Kromkamp 1999), are especially susceptible to hydrodynamic forcings such as tidal shallowing and deepening of the water column and water mass advection (de Jonge \& van Beusekom 1995, Verity et al. 1998, Lucas et al. 1999a,b, Lucas \& Cloern 2002). 
On short time scales such as hours or days (e.g. diel or tidal), there is a general lack of information concerning variability of phytoplankton biomass or taxonomic composition and even less information on controlling factors. Studies in several systems have shown that there can be considerable (and often predictable) variability over tidal cycles. Shaffer \& Sullivan (1988) found that within ca. $3 \mathrm{~h}$ after an oceanic water mass entered a lagoonal estuary on the flood tide, water column primary productivity had increased by several orders of magnitude in this same water mass, due to resuspension of benthic diatoms. In the Branford Harbor estuary, Baillie \& Welsh (1980) found that benthic diatoms were resuspended at low tide via convective currents, and as they settled, chlorophyll a decreased during the course of the flood tide. Mallin et al. (1999) also found considerable variability in chlorophyll a from high tide to low tide in several North Carolina tidal creeks. Chlorophyll a generally was higher at low tide, attributable primarily to importation of phytoplankton from upstream areas on the ebb tide. In a review of a 10 yr daily sampling program in North Inlet estuary, South Carolina, Morris (2000) found that on average, chlorophyll a was $\sim 1 \mu \mathrm{g} \mathrm{l}^{-1}$ lower at high tide than at low tide, suggesting that tidal shallowing and deepening may affect phytoplankton biomass and perhaps affect benthic grazing controls. In addition to short-term effects on phytoplankton biomass, Lucas et al. (1999a) and Lucas \& Cloern (2002) suggested that tidally influenced changes in water column height can affect the long-term (weekly to seasonal) net population growth of phytoplankton by intensifying or weakening the effect of benthic grazing and by influencing the amount of light available to phytoplankton.

North Inlet estuary is a high-salinity salt marsh located near Georgetown, South Carolina. Lewitus et al. (1998) demonstrated that at low tide during the annual summer phytoplankton bloom, microzooplankton exerted a strong grazing control on phytoplankton community growth, with the majority of the grazing effect on nano-flagellates and small diatoms, although some diatoms $>20 \mu \mathrm{m}$ were also affected. Previous work in North Inlet and other estuaries has suggested that oysters can also have a large impact on phytoplankton biomass (Dame et al. 1984, Wetz et al. 2002, Cressman et al. 2003) and taxonomic composition (Wetz et al. 2002). Although grazing has a strong impact on phytoplankton in North Inlet, there is anecdotal evidence that physical processes may also influence phytoplankton properties on relatively short time scales (i.e. over tidal cycles) (Dame et al. 1984, Morris 2000). We conducted a study of phytoplankton pigment biomass and taxonomic composition over complete tidal cycles in North Inlet creeks to assess the short-term variability in these properties and to de- termine the relative importance of abiotic (i.e. tidal forcing) vs. biotic (i.e. grazing) processes as controlling factors

\section{MATERIALS AND METHODS}

Site description. This study was conducted in 2 tidal creeks of North Inlet, a 3200 ha pristine salt-marsh estuary located near Georgetown, South Carolina, USA. Mean tidal range is approximately $1.7 \mathrm{~m}$, with semidiurnal tides. Water temperatures range from $8^{\circ} \mathrm{C}$ in January to $30^{\circ} \mathrm{C}$ or higher in July and August, and salinities are high $(>30)$ due to lack of freshwater input, with the exception of episodic heavy rain events. Seasonal cycles of chlorophyll $a$ in the study creeks follow typical patterns for North Inlet tidal creeks, with an annual chlorophyll a maximum in the summer (Lewitus et al. 1998). Ammonium and phosphate concentrations follow a similar pattern, with summer maxima and low concentrations in the winter (Lewitus et al. 1998, Morris 2000, Dame et al. 2002). Nitrate concentrations are generally low $\left(<0.5 \mu \mathrm{mol} \mathrm{l}^{-1}\right)$ from the spring through fall, with slightly elevated concentrations during the winter. Because of their shallow depth, the tidal creeks are well mixed with respect to salinity and temperature, and concentrations of dissolved substances are usually vertically uniform. Spartina alterniflora is the dominant flora, and the oyster Crassostrea virginica dominates the benthic macrofauna.

Creeks 3 and 4 are located in the Clambank system (Fig. 1), and are relatively small (164 and $229 \mathrm{~m}$ long, respectively) and narrow (6.7 and $4.6 \mathrm{~m}$ at mouth, respectively). With the exception of isolated tide pools, these creeks are typically empty at low tide. Water volume at bank-full elevation (i.e. high tide) in Creek 3 is approximately $527 \mathrm{~m}^{3}$, and in Creek 4 is $520 \mathrm{~m}^{3}$ (Corbett \& Humphries unpubl. data; available at http://links.baruch.sc.edu/Data/CREEK/CreekProject Overview/index.html). The creeks were used in a large-scale ecosystem manipulation study that examined the role of oyster reefs in controlling the function of intertidal creeks (Dame et al. 2002). In February 1998, all live oysters were removed from Creek 4, but were left intact in Creek 3. Prior to beginning our comparative study of these 2 creeks, oyster biomass was determined in June 2000, averaging $2.78 \mathrm{~g}$ dry body weight (gdb) $\mathrm{m}^{-3}$ at bank-full volume in Creek 3 and $0.48 \mathrm{gdb} \mathrm{m}^{-3}$ in Creek 4 .

Sampling methodology. Sampling took place over tidal cycles and began at mid-morning (ca. 09:00 h local time) on 5 dates in 2000: 8 July, 24 July, 7 August, 23 August and 20 September. Samples were taken at the mouth of each creek and at a site located approximately $60 \mathrm{~m}$ inside each creek at 3 time points on flood 


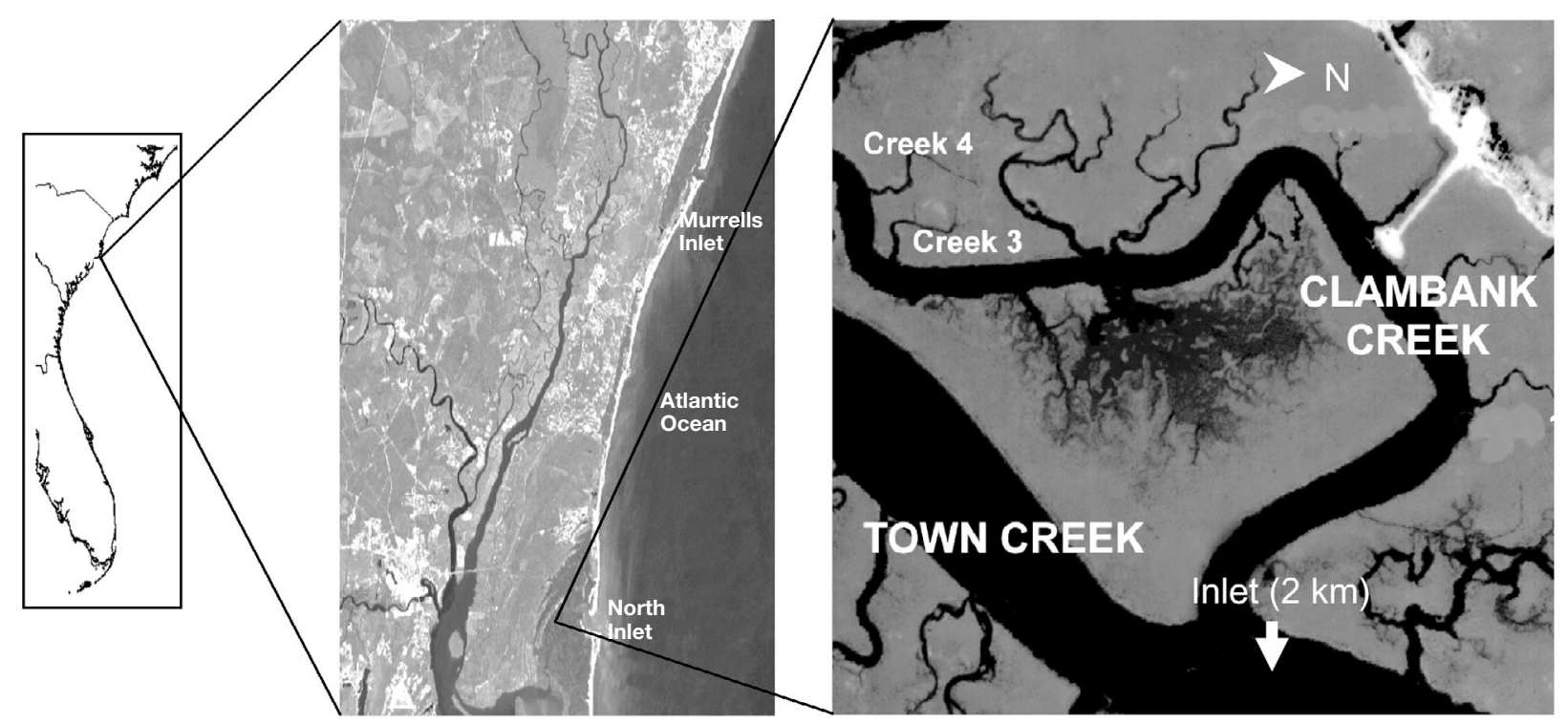

Fig. 1. North Inlet estuary, near Georgetown, South Carolina, USA, showing the 2 creeks sampled in this study during July to September 2000

tide (low $+2 \mathrm{~h}$, mid-flood, high $-1 \mathrm{~h}$ ), and at 3 points on the ebb tide (high $+1 \mathrm{~h}$, mid-ebb, and low $-2 \mathrm{~h}$ ). In the creeks, the bottom is typically exposed for about 1 to $1.5 \mathrm{~h}$ on either side of low tide. The data reported in this study are from the site located $60 \mathrm{~m}$ inside each creek, which would be most reflective of within-creek ecological processes.

Biological and chemical analyses. Water samples were collected in acid-washed 1 l, high-density, polyethylene bottles and stored in coolers for transport back to the field laboratory, where they were processed within $45 \mathrm{~min}$. Duplicate (plankton abundance) and triplicate (HPLC, nutrients) samples were taken from the same bottle. Samples for diatom abundance were preserved in 3\% acidified Lugol's solution, and abundances were determined using a modified Utermöhl settling chamber method. Flagellates were preserved in $1 \%$ glutaraldehyde, stained with 4'6diamidino-2-phenylindole (DAPI) following Porter \& Feig (1980), vacuum-filtered onto a $2.0 \mu \mathrm{m}$ black polycarbonate filter at $<5 \mathrm{~mm} \mathrm{Hg}$, and examined using an epifluorescence microscope. Phototrophs and heterotrophs were differentiated by alternating between ultraviolet (DAPI fluorescence) and green excitation (pigment autofluorescence). Dissolved nutrients were analyzed from water that had been filtered through precombusted $\left(450^{\circ} \mathrm{C}\right.$ for $\left.24 \mathrm{~h}\right)$ Whatman GF/F filters. Ammonium $\left(\mathrm{NH}_{4}{ }^{+}\right)$, nitrate/nitrite $\left(\mathrm{NO}_{3}{ }^{-}+\mathrm{NO}_{2}{ }^{-}\right)$and orthophosphate $\left(\mathrm{PO}_{4}{ }^{3-}\right)$ were determined using a Technicon Auto-analyzer II according to standard wet chemical methods (described in Belle W. Baruch Institute for Marine Biology and Coastal Research Data Archive; available at http://links.baruch.sc.edu/Data/NE
RRWCHEM/metadata/NERRWCHEM.metadata.htm).

Samples for HPLC pigment analysis were vacuumfiltered ( $<5 \mathrm{~mm} \mathrm{Hg}$ ) onto Whatman GF/F filters, which were then stored at $-80^{\circ} \mathrm{C}$ until extraction and analysis of pigments. In a dimly lit room, the frozen filters were placed in a glass, $10 \mathrm{ml}$, tissue homogenizer, which was held in an ice bath. HPLC-grade acetone (Fisher Scientific) was added $(2 \mathrm{ml})$, and the sample was pulverized with a Teflon pestle. The resulting slurry was filtered through a $13 \mathrm{~mm}, 0.2 \mu \mathrm{m}$ PTFE syringe filter (Pall Gelman Laboratory), and the filtrate was stored at $-20^{\circ} \mathrm{C}$ until analysis. The samples were analyzed using a Beckman system Gold HPLC (Beckman Coulter) according to Lewitus et al. (2005).

Phytoplankton taxonomic composition was assessed from pigment ratios using CHEMTAX, a matrix factorization program (Mackey et al. 1996). CHEMTAX uses a steepest-descent algorithm to fit a matrix containing the expected pigment ratios of several taxonomic groups to one consisting of the actual pigment content of unknown samples. However, the predictive capabilities of CHEMTAX are dependent on the pigment ratios used for calibration (Mackey et al. 1996), and thus the CHEMTAX pigment calibration ratios used in this study were obtained primarily from estuarine phytoplankton isolates (Lewitus et al. 2005). CHEMTAX calibrated in this manner has a high predictive capability for North Inlet phytoplankton assemblages (Lewitus et al. 2005). Descriptions of the phytoplankton groups resolved in this study are given in Table 1.

Tidal dilution estimates. A comparison was made of chlorophyll a concentrations at the tidal stage at which lowest concentrations were observed, i.e. $\mathrm{HIGH}+1$, 
Table 1. Nomenclature used for taxonomic groups examined in this study

\begin{tabular}{|c|c|}
\hline Group & Description \\
\hline Diatoms & $\begin{array}{l}\text { Diatoms; may include dinoflagellates with } \\
\text { chloroplasts derived from endosymbiont } \\
\text { diatoms }\end{array}$ \\
\hline DinoB & Dinoflagellates containing peridinin \\
\hline Cyano & Cyanobacteria \\
\hline PrasinoA & Prasinophytes not containing prasinoxanthin \\
\hline PrasinoB & Prasinophytes containing prasinoxanthin \\
\hline Chloro & Chlorophytes \\
\hline Crypto & Cryptophytes \\
\hline HaptoA & $\begin{array}{l}\text { Haptophytes without } 19 \text { ' hexanoyloxyfuco- } \\
\text { xanthin or } 19^{\prime} \text { butanoyloxyfucoxanthin; also } \\
\text { includes chrysophytes and dinoflagellates } \\
\text { with similar pigment compositions }\end{array}$ \\
\hline HaptoB & $\begin{array}{l}\text { Haptophytes with } 19^{\prime} \text { hexanoyloxyfuco- } \\
\text { xanthin or } 19^{\prime} \text { butanoyloxyfucoxanthin }\end{array}$ \\
\hline RaphidoA & $\begin{array}{l}\text { Raphidophytes (based on Heterosigma } \\
\text { akashiwo pigment profile) }\end{array}$ \\
\hline Eugleno & Euglenophytes \\
\hline ChrysoB & $\begin{array}{l}\text { Chrysophytes with } 19 \text { ' butanoyloxyfuco- } \\
\text { xanthin; this group was excluded from our } \\
\text { analyses because it always comprised } \leq 1 \% \\
\text { of community chlorophyll } a\end{array}$ \\
\hline
\end{tabular}

versus predicted chlorophyll a concentrations at $\mathrm{HIGH}+1$ assuming dilution by the incoming tide. Predicted chlorophyll a concentrations at $\mathrm{HIGH}+1$ were calculated using the equation:

$$
\begin{aligned}
& \mathrm{C}_{\text {predicted }}= \\
& {\left[\left(\mathrm{C}_{\mathrm{L}+2} \times \mathrm{V}_{\mathrm{L}+2}\right)+\left(\mathrm{C}_{\text {Incoming }} \times \mathrm{V}_{\text {Incoming }}\right)\right] / \mathrm{V}_{\mathrm{H}+1}}
\end{aligned}
$$

where $\mathrm{C}_{\text {predicted }}$ is the predicted chlorophyll a concentration at $\mathrm{HIGH}+1, \mathrm{C}_{\mathrm{L}+2}$ is the chlorophyll a concentration at $\mathrm{LOW}+2$ on each date, $\mathrm{V}_{\mathrm{L}+2}$ is the estimated volume of water in the creeks at $\mathrm{LOW}+2, \mathrm{C}_{\text {Incoming }}$ is the chlorophyll a concentration in the water entering the creek, $\mathrm{V}_{\text {Incoming }}$ is the estimated amount of water that enters the creek from $\mathrm{LOW}+2$ to $\mathrm{HIGH}+1$, and $\mathrm{V}_{\mathrm{H}+1}$ is the bank-full volume of water in the creeks at $\mathrm{HIGH}+1$. Water volume estimates at $\mathrm{LOW}+2$ and bank-full were determined from in situ observations and from hypsometric curves generated from geomorphological surveys performed in each creek (Corbett \& Humphries unpubl. data). Water volume entering the creek from LOW +2 to $\mathrm{HIGH}+1$ was calculated as the difference in volume between the 2 tidal stages. Chlorophyll a concentrations in the incoming water were assumed to be equal to the chlorophyll a concentrations measured at the mouth of each creek at $\mathrm{HIGH}+1$, when the upstream (i.e. within-estuary) influence of coastal water should be maximal (Table 2).
The percentage of decrease in chlorophyll a from $\mathrm{LOW}+2$ to $\mathrm{HIGH}+1$ due to tidal dilution was estimated using the equation:

$$
\begin{aligned}
& \text { Decrease in chlorophyll a }(\%)= \\
& 100 \% \times\left[\left(\mathrm{C}_{\mathrm{L}+2}-\mathrm{C}_{\text {predicted }}\right) /\left(\mathrm{C}_{\mathrm{L}+2}-\mathrm{C}_{\mathrm{H}+1}\right)\right]
\end{aligned}
$$

where $\mathrm{C}_{\mathrm{H}+1}$ is the measured chlorophyll a concentration at $\mathrm{HIGH}+1$. These calculations were not performed for 7 August because of obvious wind-induced resuspension of chlorophyll within the estuary and at the mouth of the creeks on this day.

Microzooplankton grazing bioassays. Dilution bioassays (Landry \& Hassett 1982) were used to estimate apparent phytoplankton growth rates and microzooplankton grazing rates from samples collected at midflood, HIGH + 1, and LOW-2, and also at mid-ebb on 1 date. Prior to each assay, all experimental equipment was thoroughly cleaned and bathed in $10 \% \mathrm{HCl}$ for 6 to $24 \mathrm{~h}$ and rinsed with copious amounts of deionized water. Samples used for the bioassays were brought back to the laboratory and processed within $1 \mathrm{~h}$ of collection. A portion of the water was filtered at $<5 \mathrm{~mm}$ $\mathrm{Hg}$ through sterile filter capsules $(0.2 \mu \mathrm{m}$ pore size $)$ made of cellulose acetate. The filtrate was mixed with unfiltered site water to dilutions of $10,20,33,50$ and $100 \%$ whole water and transferred into sterile, duplicate $500 \mathrm{ml}$ tissue culture flasks. The flasks were then placed in an incubator set to in situ temperatures. Lighting was provided by cool-white fluorescent lights at $75 \mu \mathrm{mol}$ quanta $\mathrm{m}^{-2} \mathrm{~s}^{-1}$ on a 14:10 h light:dark cycle. Samples were taken at 0,24 , and $72 \mathrm{~h}$ for HPLC pigment analysis, chlorophyll $a$, and Lugol-fixed samples. Phytoplankton growth rates and microzooplankton grazing rates are reported from the $24 \mathrm{~h}$ incubations and were estimated from regressions of the apparent phytoplankton growth rate from each incubation flask vs. the fraction of diluted water, with the resulting $y$-intercept equal to the growth rate, and the slope equal to the microzooplankton grazing rate. On 24 July, 7 August and 20 September, 2000, dilution bioassays with nutrient additions were performed simultaneously with the non-nutrient addition bioassays in order to assess the potential for nutrient limitation. Nitrate and phosphate were added to the experimental

Table 2. Chlorophyll a concentration ( $\mu \mathrm{g} \mathrm{l}^{-1}$; mean, SD in parentheses) at the mouths of tidal creeks at high tide $+1 \mathrm{~h}$

\begin{tabular}{|lrr|}
\hline Date (2000) & \multicolumn{1}{c}{ Creek 3 } & \multicolumn{1}{c|}{ Creek 4 } \\
\hline 8 July & $4.95(0.10)$ & $5.79(0.26)$ \\
24 July & $7.43(0.62)$ & $6.67(0.13)$ \\
7 August & $16.65(1.62)$ & $13.17(1.89)$ \\
23 August & $3.93(0.07)$ & $4.57(0.54)$ \\
20 September & $5.39(0.55)$ & $5.96(0.01)$ \\
\hline
\end{tabular}


bottles at $f / 2$ concentrations. Silicate was not added because silicate concentrations during the summer in North Inlet are generally $>25 \mu \mathrm{mol} \mathrm{l^{-1 }}$ and usually $>5$-fold higher than DIN concentrations (Lewitus et al. 2004, White et al. 2004), and are unlikely to limit diatom growth during the incubations or in situ. Growth rates averaged only $3 \%$ higher in the nutrient addition bioassays and were not significantly different from the non-nutrient addition bioassays (2-sided t-test; $\mathrm{p}=0.87, \mathrm{n}=11$ ) (data not shown). Phytoplankton taxonomic group growth rates, based on HPLC pigments, and microzooplankton grazing rates on those groups were estimated from the $72 \mathrm{~h}$ incubations to ensure that acceptable pigment concentrations could be determined from the higher dilutions. Whereas these results are indicative of preferential grazing activity, their relevance as estimates of growth and grazing coefficients based on the dilution technique is limited, because the long incubation period can lead to an experimentally altered community (Gallegos \& Jordan 1997).

Several of the dilution experiments (9 out of 30 ) exhibited non-linear (i.e. saturated) feeding kinetics; therefore we used the 3-point method of Gallegos (1989) to estimate growth rates from those. To account for the inherent bias of the 3-point method for estimating grazing rates when there might be microzooplankton growth during incubation, we used Gallegos' (1989) Eq. (11) to estimate grazing rates and measured ciliate growth rates in a select set of incubations. Ciliates and small ( $<5$ to $10 \mu \mathrm{m})$ heterotrophic nanoflagellates are the dominant microzooplankton in North Inlet, and heterotrophic dinoflagellate abundances are typically low (Lewitus et al. 2002, Wetz et al. 2002, Wetz unpubl. data). Given their small size, the heterotrophic nanoflagellates are probably bacterivorous (Sherr et al. 1989) and should not contribute to the chlorophyll-based grazing estimates used in this study. Net ciliate growth rates, determined from changes in abundance over time, averaged $0.29 \mathrm{~d}^{-1}(\mathrm{SE}=0.12, \mathrm{n}=8$ ) in undiluted incubations. Because we had only a small number of ciliate growth measurements, we estimated how much the grazing rates would change if ciliate growth were set to 0 or $0.5 \mathrm{~d}^{-1}$. Setting ciliate growth to $0 \mathrm{~d}^{-1}$ would result in an average $9 \%$ increase in the grazing rates, while setting ciliate growth to $0.5 \mathrm{~d}^{-1}$ would result in an average $7 \%$ decrease.

A recent concern raised regarding the reliability of dilution experiments is that ciliate mortality in the most dilute incubations (ca. $10 \%$ of whole water) can result in overestimates of grazing rates and that dilution experiments are unlikely to yield low grazing rates (Dolan et al. 2000). Although we did not measure ciliate abundances in the more dilute treatments of our dilution experiments, we believe that we have not systematically overestimated grazing rates. Low to statistically non-significant grazing rates were obtained, indicative of low grazing pressure (Landry \& Calbet 2004).

\section{RESULTS}

On all dates, water levels were $<0.5 \mathrm{~m}$ at the start of sampling. By high tide, water levels were at or over the top of the creek banks (ca. $2 \mathrm{~m}$ ). Water flow into the creeks ceased between HIGH-1 and HIGH + 1, except on 7 August, when strong winds forced the water to flow into the creeks until between $\mathrm{HIGH}+1$ and midebb. On all dates, water had begun to flow out of the creeks by mid-ebb. Water velocities followed a pattern similar to that of previous studies in North Inlet tidal creeks (e.g. Dame et al. 1985, Kjerfve et al. 1991), with maximal water velocities between mid-ebb and LOW-2 (data not shown). Water temperature in the creeks ranged from 26 to $32^{\circ} \mathrm{C}$, and was slightly lower on 20 September than on the other dates (Fig. 2). On the first 4 sampling dates, salinities ranged from 34 to 37 , except on 24 July when salinity at LOW +2 averaged 31 due to a brief period of rainfall the night before. Salinity reached 35 by mid-flood on that date
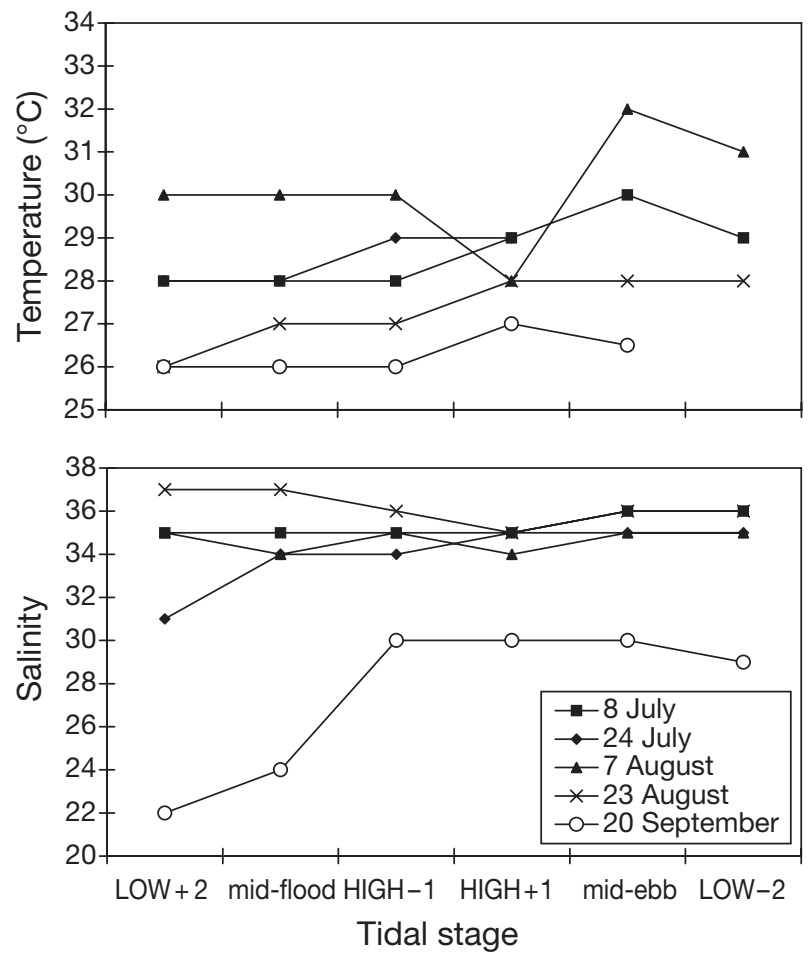

Fig. 2. Water temperature $\left({ }^{\circ} \mathrm{C}\right)$ and salinity over tidal cycles in Creek 3 (same patterns were observed in Creek 4, data not shown) 
and varied little $(\geq 2)$ over the tidal cycle on the other dates. On 20 September, salinity averaged 22 at LOW +2 due to the passage of Tropical Storm Gordon on 18 September, and had only reached 30 by high tide.

Considerable short-term (tidal cycle) variability in phytoplankton pigment biomass and taxonomic composition was evident. Chlorophyll a decreased significantly during the course of the tidal cycle and usually reached a minimum by $\mathrm{HIGH}+1$ (Fig. 3). Chlorophyll a decreased by an average of $47 \%$ in Creek 3 and $51 \%$ in Creek 4 from LOW +2 to $\mathrm{HIGH}+1$. From $\mathrm{LOW}+2$ to LOW-2, chlorophyll a decreased by an average of $33 \%$ in Creek 3 and $38 \%$ in Creek 4 . For all dates sampled in Creek 3, chlorophyll a averaged $10.3 \pm 3.6 \mu \mathrm{g}$ $\mathrm{l}^{-1}$ on the flood tide and $7.5 \pm 2.9 \mu \mathrm{gl}^{-1}$ on the ebb tide, significantly different at $\mathrm{p}<0.05$ (2-sided $t$-test). For all dates sampled in Creek 4, chlorophyll a averaged $12.3 \pm 5.3 \mu \mathrm{g} \mathrm{l}^{-1}$ on the flood tide and $8.2 \pm 3.5 \mu \mathrm{g} \mathrm{l}^{-1}$ on the ebb tide, significantly different at $\mathrm{p}<0.05$ (2-sided $t$-test).

Phytoplankton taxonomic composition in the creeks was generally similar between dates (Fig. 4). Diatoms, PrasinoB and HaptoA averaged $83 \%$ of total chlorophyll $a$ in the creeks. Ebb-tide waters contained a relatively higher proportion of diatoms, which averaged 52 and $62 \%$ of chlorophyll a on flood and ebb tides, respectively, in Creek 3 ; and 55 and $60 \%$ of chlorophyll a on flood and ebb tides, respectively, in Creek 4. PrasinoB did not vary with tide, averaging 17 and $16 \%$ of chlorophyll $a$ on flood and ebb tides, respectively, in Creek 3; and 16 and $17 \%$ in Creek 4. Flood-tide waters contained a relatively higher proportion of HaptoA, which averaged 16 and $4 \%$ of chlorophyll $a$ on flood and ebb tides, respectively, in Creek 3 ; and 12 and $5 \%$ in Creek 4.

In terms of the decrease in chlorophyll a from $\mathrm{LOW}+2$ to $\mathrm{HIGH}+1$, the percent decrease caused by tidal dilution was estimated to be $88 \pm 4 \%$ in Creek 3 and $87 \pm 10 \%$ in Creek 4 . On average, decreases in flagellate (all flagellate groups combined) pigment biomass accounted for $60 \%$ of the change on the first 4 dates and $92 \%$ on 20 September. On average, decreases in diatom pigment biomass accounted for $40 \%$ of the change on the first 4 dates, but only $8 \%$ on 20 September.

Ammonium and phosphate concentrations were always highest at LOW + 2 and subsequently decreased during the course of the tidal cycle. Overall, concentrations of both were higher on the flood tide than on the ebb tide (Table 3). Ammonium concentrations were 2- to 3-fold higher on 20

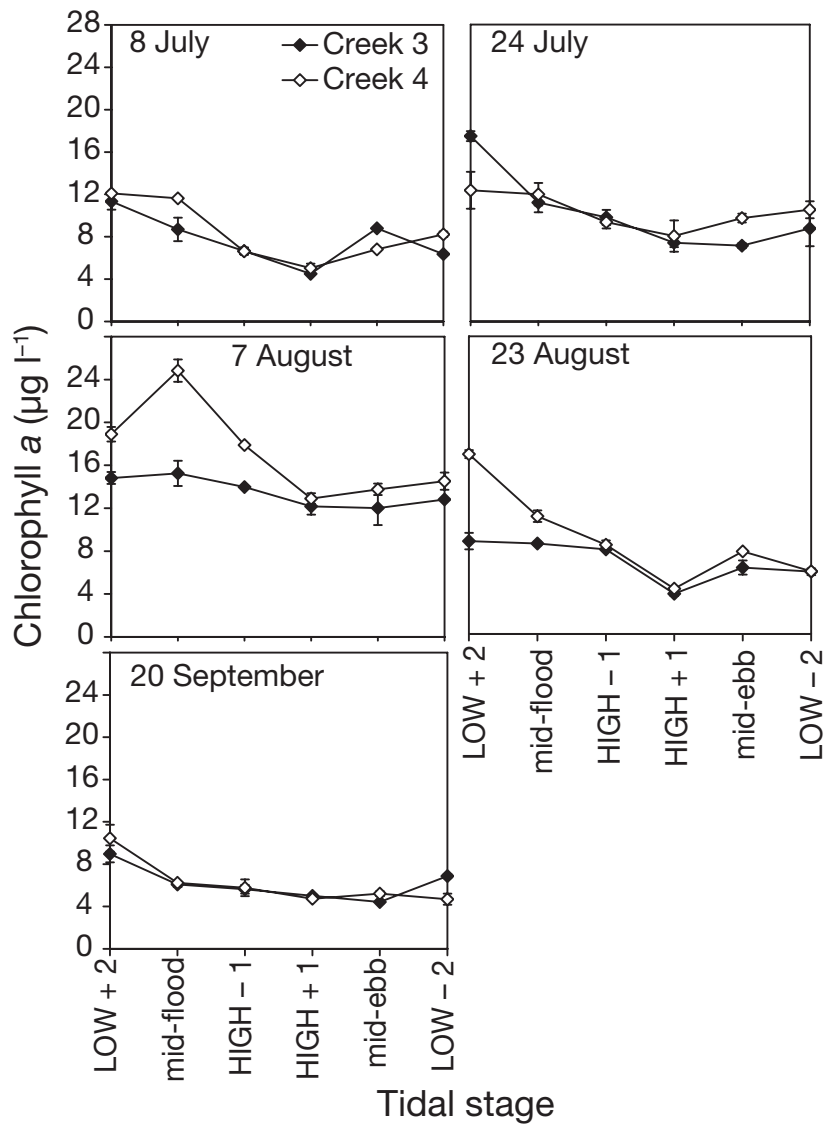

Fig. 3. Chlorophyll $a$ in Creeks 3 and 4 over tidal cycles

September than on the other dates, coincident with the passage of Tropical Storm Gordon on 18 September. Dissolved organic nitrogen (DON) concentrations varied little over the tidal cycle, and averaged 10.6 \pm 3.6 $\mu \mathrm{mol} \mathrm{l}^{-1}$ on the first 4 dates, but only $2.8 \pm 2.3 \mu \mathrm{mol} \mathrm{l}^{-1}$ on the last date (data not shown).

Phytoplankton growth rates ranged from 1.11 to $3.37 \mathrm{~d}^{-1}$ (mean $\pm \mathrm{SD}=1.75 \pm 0.57 \mathrm{~d}^{-1}$ ), while microzooplankton grazing rates ranged from 0.14 to $3.06 \mathrm{~d}^{-1}$ $\left(\right.$ mean $\left.\pm \mathrm{SD}=1.19 \pm 0.81 \mathrm{~d}^{-1}\right)($ Table 4$)$. The mean growth rate was lower on 20 September than on the

Table 3. Mean $( \pm \mathrm{SD})$ nutrient concentrations $\left(\mu \mathrm{mol}^{-1}\right)$ in tidal creeks on flood and ebb tides

\begin{tabular}{|lrccccc|}
\hline \multirow{2}{*}{$\begin{array}{l}\text { Date } \\
(2000)\end{array}$} & \multicolumn{2}{c}{$\mathrm{NH}_{4}{ }^{+}$} & \multicolumn{2}{c}{$\mathrm{NO}_{3}{ }^{-}+\mathrm{NO}_{2}{ }^{-}$} & \multicolumn{2}{c|}{$\mathrm{PO}_{4}{ }^{3-}$} \\
& \multicolumn{1}{c}{ Flood } & Ebb & Flood & Ebb & Flood & Ebb \\
\hline 8 July & $4.5 \pm 1.0$ & $2.6 \pm 1.6$ & $0.1 \pm 0.1$ & $0.1 \pm 0.1$ & $0.3 \pm 0.2$ & $0.1 \pm 0.0$ \\
24 July & $7.3 \pm 2.6$ & $3.0 \pm 0.6$ & $1.3 \pm 0.2$ & $0.4 \pm 0.1$ & $0.5 \pm 0.1$ & $0.4 \pm 0.1$ \\
7 August & $2.6 \pm 2.1$ & $0.9 \pm 0.2$ & $0.3 \pm 0.1$ & $0.3 \pm 0.2$ & $0.5 \pm 0.2$ & $0.3 \pm 0.1$ \\
23 August & $4.5 \pm 1.9$ & $1.4 \pm 0.8$ & $0.1 \pm 0.1$ & $0.0 \pm 0.0$ & $0.3 \pm 0.3$ & $0.2 \pm 0.0$ \\
20 September & $12.4 \pm 2.9$ & $6.7 \pm 2.0$ & $1.7 \pm 0.5$ & $0.6 \pm 0.1$ & $0.2 \pm 0.1$ & $0.1 \pm 0.1$ \\
Mean & $6.3 \pm 3.8$ & $2.9 \pm 2.3$ & $0.7 \pm 0.7$ & $0.3 \pm 0.2$ & $0.4 \pm 0.1$ & $0.2 \pm 0.1$ \\
\hline
\end{tabular}



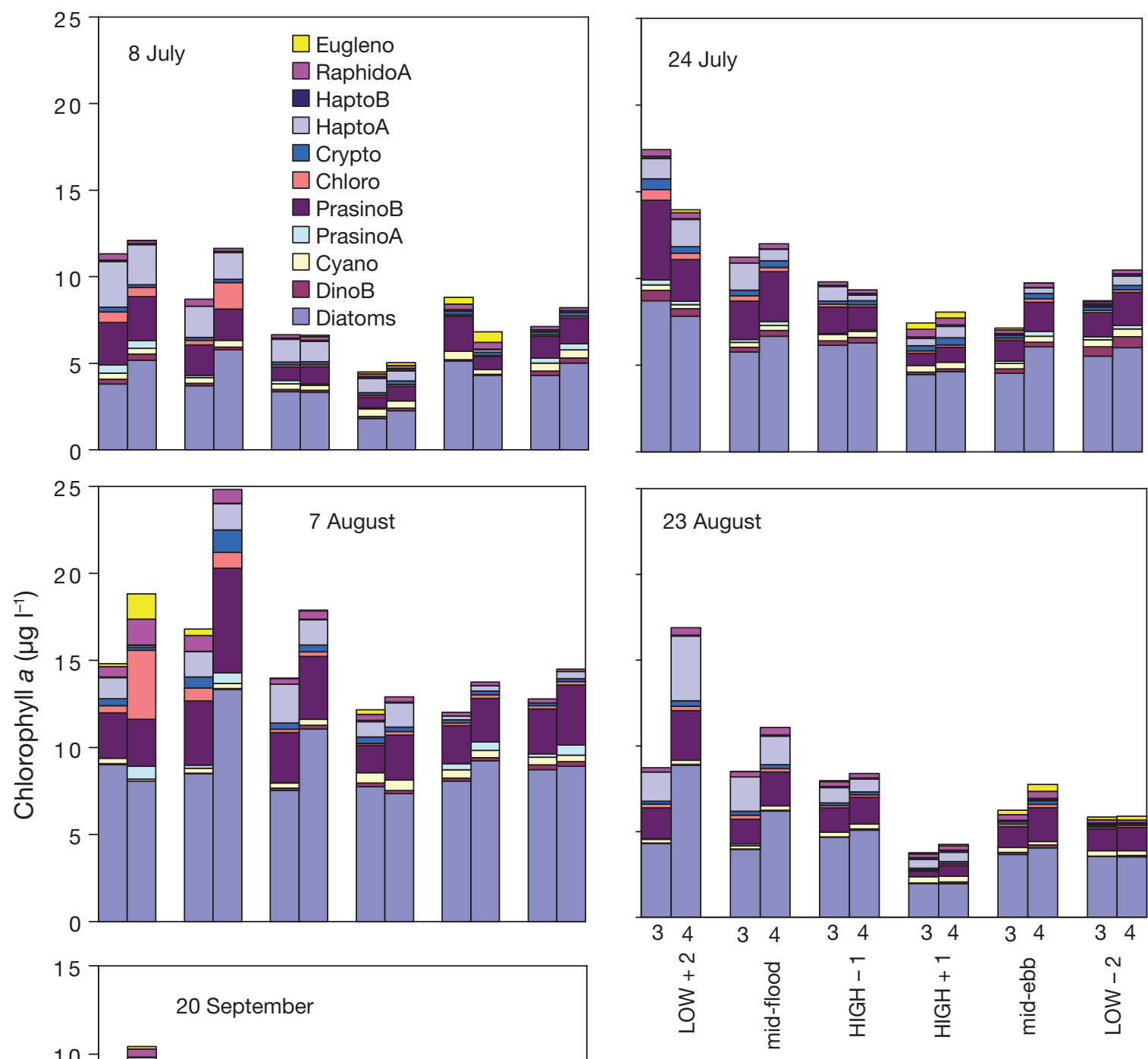

Tidal stage

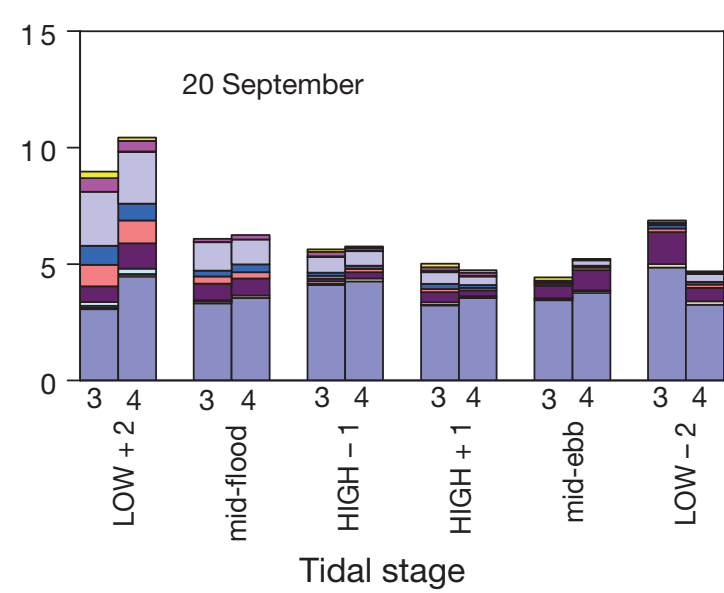

Fig. 4. Phytoplankton taxonomic composition in Creeks 3 and 4 over tidal cycles. (Taxonomic groups described in Table 1)

other 4 dates $\left(1.29 \pm 0.12\right.$ vs. $\left.1.87 \pm 0.58 \mathrm{~d}^{-1}\right)$, as was the mean grazing rate $\left(0.37 \pm 0.13\right.$ vs. $\left.1.39 \pm 0.78 \mathrm{~d}^{-1}\right)$. The percentage of grazing rates to growth rates averaged $74 \pm 36 \%$ on the first 4 dates, but only $29 \pm 9 \%$ on 20 September, and was significantly different at $\mathrm{p}<0.01$ (2-sided $t$-test).

In general, the percentage of grazing rate to growth rate was lower for diatoms than for PrasinoB or HaptoA
(Table 5), and was statistically lower for diatoms than PrasinoB for the first 4 dates (2-sided $t$-test, $\mathrm{p}<0.01)$. For the diatoms, it averaged $103 \pm 33 \%$ on those dates, but varied considerably by date and tidal stage, ranging from 50 to $163 \%$. For PrasinoB, it averaged $176 \pm 82 \%$ and ranged from 96 to $312 \%$, and for HaptoA it averaged $116 \pm 76 \%$ and ranged from 43 to $290 \%$. 
Table 4. Mean (SE) phytoplankton growth rates and microzooplankton grazing rates in tidal creeks at various stages of tide in summer, 2000. ${ }^{*}$ Grazing rate significantly different from zero at $\mathrm{p}<0.05$ (2-sided $t$-test)

\begin{tabular}{|c|c|c|c|c|}
\hline Tide & Creek & $\begin{array}{l}\text { Growth } \\
\text { rate }\end{array}$ & $\begin{array}{l}\text { Grazing } \\
\text { rate }\end{array}$ & $\begin{array}{l}\text { Grazing: } \\
\text { growth (\%) }\end{array}$ \\
\hline \multicolumn{5}{|l|}{8 July } \\
\hline Mid-flood & 4 & $1.90(0.11)$ & $1.97(0.22)^{*}$ & 104 \\
\hline \multirow{2}{*}{$\mathrm{HIGH}+1 \mathrm{~h}$} & 3 & $1.87(0.10)$ & $1.16(0.19)^{*}$ & 62 \\
\hline & 4 & $1.89(0.05)$ & $1.91(0.09)^{*}$ & 101 \\
\hline \multirow[t]{2}{*}{ Mid-ebb } & 3 & $1.77(0.07)$ & $2.18(0.13)^{*}$ & 123 \\
\hline & 4 & $1.65(0.05)$ & $2.17(0.10)^{*}$ & 132 \\
\hline \multirow[t]{2}{*}{ LOW - $2 \mathrm{~h}$} & 3 & $1.44(0.07)$ & $1.62(0.14)^{*}$ & 113 \\
\hline & 4 & $1.12(0.08)$ & $1.38(0.15)^{*}$ & 123 \\
\hline \multicolumn{5}{|l|}{24 July } \\
\hline \multirow[t]{2}{*}{ Mid-flood } & 3 & $1.63(0.02)$ & $0.56(0.04)^{*}$ & 34 \\
\hline & 4 & $1.41(0.03)$ & $0.55(0.06)^{*}$ & 39 \\
\hline $\mathrm{HIGH}+1 \mathrm{~h}$ & 4 & $1.15(0.05)$ & $0.61(0.09)^{*}$ & 53 \\
\hline \multirow[t]{2}{*}{ LOW - $2 \mathrm{~h}$} & 3 & $1.47(0.03)$ & $0.41(0.06)^{*}$ & 28 \\
\hline & 4 & $1.86(0.07)$ & $1.33(0.06)^{*}$ & 72 \\
\hline \multicolumn{5}{|l|}{7 August } \\
\hline \multirow[t]{2}{*}{ Mid-flood } & 3 & $1.79(0.01)$ & $0.22(0.02)^{*}$ & 12 \\
\hline & 4 & $1.72(0.02)$ & $0.31(0.04)^{*}$ & 18 \\
\hline \multirow[t]{2}{*}{$\mathrm{HIGH}+1 \mathrm{~h}$} & 3 & $2.23(0.16)$ & $1.55(0.27)^{*}$ & 70 \\
\hline & 4 & $1.96(0.08)$ & $1.23(0.14)^{*}$ & 63 \\
\hline \multirow[t]{2}{*}{ LOW - $2 \mathrm{~h}$} & 3 & $2.96(0.05)$ & $2.37(0.03)^{*}$ & 80 \\
\hline & 4 & $3.18(0.06)$ & $2.63(0.08)^{*}$ & 83 \\
\hline \multicolumn{5}{|l|}{23 August } \\
\hline \multirow[t]{2}{*}{ Mid-flood } & 3 & $2.04(0.23)$ & $0.81(0.44)$ & 40 \\
\hline & 4 & $1.25(0.04)$ & $0.84(0.07)^{*}$ & 67 \\
\hline \multirow[t]{2}{*}{$\mathrm{HIGH}+1 \mathrm{~h}$} & 3 & $1.80(0.08)$ & $1.67(0.16)^{*}$ & 93 \\
\hline & 4 & $3.37(0.38)$ & $3.06(0.24)^{*}$ & 91 \\
\hline \multirow[t]{2}{*}{ LOW $-2 \mathrm{~h}$} & 3 & $1.96(0.04)$ & $0.93(0.07)^{*}$ & 47 \\
\hline & 4 & $1.38(0.16)$ & $1.86(0.30)^{*}$ & 135 \\
\hline \multicolumn{5}{|c|}{20 September } \\
\hline \multirow[t]{2}{*}{ Mid-flood } & 3 & $1.25(0.02)$ & $0.14(0.04)^{*}$ & 11 \\
\hline & 4 & $1.41(0.07)$ & $0.48(0.09)$ & 34 \\
\hline \multirow[t]{2}{*}{$\mathrm{HIGH}+1 \mathrm{~h}$} & 3 & $1.41(0.07)$ & $0.47(0.13)$ & 33 \\
\hline & 4 & $1.31(0.15)$ & $0.47(0.28)$ & 36 \\
\hline \multirow{2}{*}{ LOW $-2 \mathrm{~h}$} & 3 & $1.23(0.07)$ & $0.36(0.01)^{*}$ & 29 \\
\hline & 4 & $1.11(0.02)$ & $0.30(0.01)^{*}$ & 27 \\
\hline
\end{tabular}

\section{DISCUSSION}

During the productive summer season in North Inlet, we found considerable short-term (i.e. tidal cycle) variability in phytoplankton pigment biomass and taxonomic composition. This variability led to a predictable pattern in these parameters and implies that strict attention must be paid to tidal stage when comparing eutrophication status between estuaries similarly influenced by tides, and in determining long-term trends in phytoplankton biomass and primary productivity.
Additionally, this tidal cycle variability has implications for food web dynamics and biogeochemical cycles in North Inlet and similar estuaries. For instance, concentration of phytoplankton biomass in the water column on either side of low tide increases their accessibility to benthic grazers. However, the subsequent dilution and settling of that biomass during most of the remaining tidal cycle effectively limits the time in which the benthic grazers are exposed to this food source. Furthermore, tidally driven interactions between the phytoplankton and benthic grazers may ultimately affect the long-term net phytoplankton growth and productivity (e.g. Lucas \& Cloern 2002). Tidally driven changes in phytoplankton taxonomic composition also influence key biogeochemical cycles of carbon and sulfur in shallow coastal systems. Jouenne et al. (2005) found that tidal variations in phytoplankton taxonomic composition significantly influenced the overall productivity of the phytoplankton community, and Kulkarni et al. (2005) found that the extent of DMSP production was strongly controlled by tidally driven changes in phytoplankton taxonomic composition.

In our study creeks, chlorophyll a decreased by ca. 47 to $51 \%$ from low tide to $1 \mathrm{~h}$ after high tide, but began to increase again towards the end of ebb tide. Of the chlorophyll $a$ found in the water column, benthic microalgae contributed $\sim 10$ to $30 \%$ on either side of low tide, but only $\sim 5$ to $10 \%$ at high tide. Benthic microalgae can comprise a significant portion of the water column chlorophyll $a$ in estuarine systems (e.g. de Jonge \& van Beusekom 1995). Dilution by incoming lower chlorophyll a coastal water was the primary cause for the decrease in chlorophyll $a$ on the flood tide, accounting for 86 to $88 \%$ of the decrease. This is consistent with the trend observed by Morris (2000) in his analysis of a $10 \mathrm{yr}$ data set in North Inlet which showed that, on average, chlorophyll a was $\sim 1 \mu g l^{-1}$ lower at high tide than at low tide in Clambank Creek. However, our results show that on any given date, the change in chlorophyll a concentrations was far more extreme, decreasing by 2.6 to $12.7 \mu \mathrm{g} \mathrm{l}^{-1}$ (mean $=6.4 \pm$ $3.0 \mu \mathrm{g}^{-1}$ ). Secondary factors behind the decrease in chlorophyll include settling (in the case of diatoms), grazing by benthic macrofauna (e.g. oysters), or microzooplankton grazing. On one sampling date (7 August) characterized by strong winds, chlorophyll a actually increased over part of the flood tide in Creek 4. This increase originated primarily from diatoms, which can be susceptible to wind-induced resuspension in shallow estuarine systems (e.g. de Jonge \& van Beusekom 1995). Aside from 7 August, however, we did not observe significant resuspension events on the flood tide, and tidal dilution and loss processes were the dominant features. In contrast to the flood tide, resus- 
Table 5. Mean (SE) phytoplankton growth rates and microzooplankton grazing rates in summer, 2000. (nd): SE could not be calculated due to lack of replication; missing data: pigment concentration was not high enough to obtain taxonomic group concentration

\begin{tabular}{|c|c|c|c|c|c|c|c|c|c|c|}
\hline \multirow{2}{*}{ Tide } & \multirow{2}{*}{ Creek } & \multirow{2}{*}{ Growth } & \multicolumn{2}{|c|}{ Diatoms $\longrightarrow$} & \multirow[b]{2}{*}{ Growth } & \multicolumn{2}{|c|}{ PrasinoB $\longrightarrow$} & \multirow[b]{2}{*}{ Growth } & \multicolumn{2}{|c|}{ HaptoA } \\
\hline & & & Grazing & $\begin{array}{c}\text { Growth: } \\
\text { grazing } \\
(\%)\end{array}$ & & Grazing & $\begin{array}{c}\text { Growth: } \\
\text { grazing } \\
(\%)\end{array}$ & & Grazing & $\begin{array}{c}\text { Growth: } \\
\text { grazing } \\
(\%)\end{array}$ \\
\hline \multicolumn{11}{|l|}{8 July } \\
\hline \multirow[t]{2}{*}{ Mid-flood } & 3 & $1.96(0.16)$ & $1.83(0.28)$ & 93 & 1.32 (nd) & 1.35 (nd) & 102 & & & \\
\hline & 4 & $0.68(0.07)$ & $0.99(0.11)$ & 145 & $0.70(0.06)$ & $1.40(0.11)$ & 200 & $0.86(0.09)$ & $0.73(0.16)$ & 85 \\
\hline \multirow[t]{2}{*}{$\mathrm{HIGH}+1$} & 3 & $1.11(0.04)$ & $1.82(0.14)$ & 163 & & & & & & \\
\hline & 4 & $1.06(0.05)$ & 0.88 (nd) & 83 & & & & & & \\
\hline \multirow[t]{2}{*}{ Mid-ebb } & 3 & 0.62 (nd) & 0.91 (nd) & 147 & & & & & & \\
\hline & 4 & 1.51 (nd) & 1.55 (nd) & 102 & & & & & & \\
\hline \multirow[t]{2}{*}{ LOW-2 } & 3 & $1.21(0.17)$ & $1.06(0.17)$ & 87 & $0.31(0.07)$ & $0.60(0.13)$ & 194 & & & \\
\hline & 4 & $0.58(0.05)$ & $0.80(0.09)$ & 138 & $0.33(0.05)$ & $1.03(0.11)$ & 312 & & & \\
\hline \multicolumn{11}{|l|}{24 July } \\
\hline \multirow{2}{*}{ Mid-flood } & 3 & $1.27(0.02)$ & $0.99(0.04)$ & 78 & $1.11(0.06)$ & $1.06(0.09)$ & 95 & & & \\
\hline & 4 & $1.16(0.09)$ & $0.65(0.18)$ & 56 & $0.78(0.06)$ & $0.91(0.04)$ & 117 & & & \\
\hline \multirow[t]{2}{*}{ HIGH + 1} & 3 & $1.00(0.02)$ & $0.66(0.20)$ & 66 & $0.57(0.06)$ & $0.82(0.12)$ & 144 & & & \\
\hline & 4 & $1.04(0.11)$ & $0.98(0.04)$ & 94 & $0.22(0.25)$ & $0.66(0.15)$ & 300 & & & \\
\hline \multirow[t]{2}{*}{ LOW-2 } & 3 & $1.17(0.04)$ & $1.00(0.05)$ & 86 & $1.10(0.30)$ & $1.36(0.15)$ & 124 & & & \\
\hline & 4 & $1.04(0.08)$ & & & & & & & & \\
\hline \multicolumn{11}{|l|}{7 August } \\
\hline Mid-flood & 4 & 1.19 (nd) & 1.04 (nd) & 88 & & & & 0.34 (nd) & 0.50 (nd) & 150 \\
\hline \multirow[t]{2}{*}{ HIGH + 1} & 3 & $0.67(0.02)$ & $0.98(0.04)$ & 146 & & & & $0.31(0.44)$ & $0.90(0.07)$ & 290 \\
\hline & 4 & $0.84(0.10)$ & $1.07(0.10)$ & 128 & & & & $0.96(0.24)$ & $0.98(0.02)$ & 102 \\
\hline \multirow[t]{2}{*}{ LOW-2 } & 3 & $0.45(0.16)$ & $0.66(0.28)$ & 146 & & & & $0.40(0.08)$ & $0.38(0.24)$ & 95 \\
\hline & 4 & $0.91(0.06)$ & $0.95(0.10)$ & 105 & & & & $0.77(0.09)$ & $0.64(0.08)$ & 83 \\
\hline \multicolumn{11}{|l|}{23 August } \\
\hline \multirow[t]{2}{*}{ Mid-flood } & 3 & $1.24(0.13)$ & $1.10(0.11)$ & 89 & & & & & & \\
\hline & 4 & $0.83(0.04)$ & $0.68(0.10)$ & 81 & & & & & & \\
\hline \multirow[t]{2}{*}{$\mathrm{HIGH}+1$} & 3 & $0.86(0.07)$ & $0.99(0.04)$ & 115 & & & & & & \\
\hline & 4 & $0.56(0.20)$ & $0.75(0.07)$ & 135 & & & & & & \\
\hline \multirow[t]{2}{*}{ LOW-2 } & 3 & $1.08(0.10)$ & $0.65(0.08)$ & 60 & & & & $0.41(0.03)$ & $0.34(0.02)$ & 83 \\
\hline & 4 & 1.06 (nd) & 0.52 (nd) & 50 & & & & 0.82 (nd) & 0.35 (nd) & 43 \\
\hline \multicolumn{11}{|c|}{20 September } \\
\hline Mid-flood & 3 & $1.37(0.03)$ & $0.74(0.06)$ & 54 & $1.15(0.06)$ & $1.05(0.12)$ & 91 & $1.08(0.06)$ & $0.80(0.11)$ & 74 \\
\hline & 4 & $1.52(0.04)$ & $-0.33(\mathrm{nd})$ & & $1.60(0.72)$ & 1.06 (nd) & 66 & $1.28(0.48)$ & 0.47 (nd) & 37 \\
\hline HIGH + 1 & 3 & $1.24(0.14)$ & $0.51(0.26)$ & 41 & & & & $1.20(0.12)$ & 1.14 (nd) & 95 \\
\hline & 4 & $1.10(0.12)$ & $-0.21(0.15)$ & & & & & & & \\
\hline LOW-2 & 3 & $1.39(0.07)$ & $0.42(0.17)$ & 31 & $1.30(0.08)$ & $0.72(0.07)$ & 55 & $1.09(0.16)$ & -0.08 (nd) & \\
\hline & 4 & $1.25(0.11)$ & $-0.08(0.01)$ & & $0.85(0.16)$ & $-0.01(0.02)$ & & $0.88(0.29)$ & $-0.37(0.22)$ & \\
\hline
\end{tabular}

pension consistently occurred towards the end of the ebb tide, probably due to higher flow velocities. Lucas et al. (2000) showed that on muddy sediments, similar to those at our sites, significant resuspension of benthic microalgae occurred at flow velocities $>15 \mathrm{~cm} \mathrm{~s}^{-1}$. Velocities of this magnitude were not seen on the flood tide except on 20 September, but velocities $>15 \mathrm{~cm} \mathrm{~s}^{-1}$ were consistently reached from mid-ebb onward. Importation of phytoplankton/benthic microalgal biomass from the marsh surface could have been an additional source of the increased chlorophyll on the ebb tide, as seen in several small North Carolina tidal creeks (e.g. Mallin et al. 1999).
Decreases in diatom biomass accounted for $~ 40 \%$ of the decrease in chlorophyll a from low to high tide on the first 4 dates. This resulted from much lower diatom biomass on the incoming tide and from loss processes primarily affecting pennate diatoms on the flood tide. From cell count data on the first date (8 July), pennate diatoms were the most abundant form at low tide (data not shown). However, their abundance decreased drastically from low tide to high tide, while the smaller chain-forming diatom, Chaetoceros sp., and other centric diatoms became more abundant. Given the low flow velocities on the flood tide (except for 20 September), the pennate diatoms probably settled rapidly 
from the beginning of the flood tide. For example, Baillie \& Welsh (1980) found that benthic diatoms were resuspended at low tide via convective currents and rapidly settled over the course of the flood tide in a New England estuary. Pinckney \& Zingmark (1991) and Pinckney et al. (1994) demonstrated that benthic diatoms migrate downward into the sediments during the flood tide in North Inlet. On 20 September, when much higher flow velocities were observed on the flood tide (ca. 12 to $20 \mathrm{~cm} \mathrm{~s}^{-1}$ from mid-flood to HIGH-1), diatoms only accounted for $\sim 8 \%$ of the decrease in chlorophyll a from LOW + 2 to $\mathrm{HIGH}+1$, indicating that they may have been kept in suspension or that the incoming tidal water may have contained higher diatom biomass than on previous dates.

Macrofaunal grazing in Creek 3 and microzooplankton grazing in both creeks may also have contributed to the pennate diatom decrease, but in a limited manner. Relatively low water levels during the flood tide would have increased accessibility to benthic macrofauna, particularly oysters, which feed on pennate diatoms (e.g. Cognie et al. 2001). However, Dame (1996) estimated that oyster biomass $>8 \mathrm{gdb} \mathrm{m}^{-3}$ was needed to significantly impact phytoplankton biomass in North Inlet tidal creeks. In Creek 3, oyster biomass at bank-full volume was only $2.78 \mathrm{gdb} \mathrm{m}^{-3}$, suggesting that oysters could not noticeably impact diatom biomass at or around high tide. Nonetheless, considering that the volume of water in Creek 3 at LOW + 2 was 1 order of magnitude lower in the early to mid-stages of the flood tide vs. at bank-full volume, oysters may have had a limited impact on the phytoplankton (including diatoms) standing stock during that portion of the tide. For microzooplankton grazing to have had a noticeable impact on the phytoplankton biomass, the percentage of microzooplankton grazing rates to phytoplankton growth rates would have had to exceed $100 \%$. This was seen in 7 out of 30 samples, but there was no consistent trend in phytoplankton growth rates vs. microzooplankton grazing rates with tidal stage or sampling date and growth rates frequently exceeded grazing rates. Furthermore, even though grazing rates on the diatoms occasionally exceeded their growth rates, the $72 \mathrm{~h}$ incubations probably enhanced the grazing effect above that occurring in situ. Thus we suspect that microzooplankton grazing on the diatoms accounted for a negligible fraction of the latter's decrease in biomass over the tidal cycle.

Decreases in flagellate biomass accounted for $\sim 60 \%$ of the change in chlorophyll a from low to high tide on the first 4 dates and $\sim 92 \%$ on the last date. These decreases were verified by microscopy, which showed that flagellate abundance decreased by $65 \%$ from low to high tide on average (data not shown). This reduction in flagellate biomass implies that the incoming coastal water must have had drastically lower flagellate concentrations than water within the estuary. High and selective microzooplankton grazing on the PrasinoB and HaptoA groups may have caused the additional decrease in their biomass as the tide came in. Notwithstanding the potential artifacts associated with the $72 \mathrm{~h}$ incubation period, the percentage of growth to grazing rate averaged much more than $100 \%$ for both groups, indicative of heavy grazing pressure. Lewitus et al. (1998) showed that microzooplankton grazing has a substantial impact on phototrophic flagellate growth during the summer in North Inlet. Also, given the lower water levels on the flood tide, oyster feeding on these groups may have been enhanced in Creek 3. Loret et al. (2000) and Dupuy et al. (2000) showed that flagellates could represent an important food source for oysters, and Wetz et al. (2002) demonstrated that phototrophic nanoflagellate biomass was significantly reduced in tidal creeks with oysters and in flumes containing oysters.

Dissolved inorganic nitrogen $\left(\mathrm{NH}_{4}{ }^{+}, \mathrm{NO}_{3}{ }^{-} / \mathrm{NO}_{2}{ }^{-}\right)$ concentrations on the flood tide in Creeks 3 and 4 were roughly 2 to 3 times higher on 20 September than on the other 4 dates, a result of freshwater input from Tropical Storm Gordon, which passed through the area 2 d earlier. Several studies of southeastern US estuaries have shown that heavy rain events can lead to pronounced increases in water column nutrient concentrations (Hubertz \& Cahoon 1999, Peierls et al. 2003, White et al. 2004). In 2 North Carolina estuaries, heavy rain events during the summer caused rapid (within $\sim 2$ to $6 \mathrm{~d}$ ) post-storm increases in chlorophyll a (Hubertz \& Cahoon 1999). No apparent increase in chlorophyll a over previous sampling dates was observed on 20 September, and phytoplankton population growth rates were slightly lower. Increased levels of organic matter (i.e. $>600 \mu \mathrm{mol} \mathrm{l^{-1 }}$ DOC, data not shown) flushed into the system, and this may have led to light limitation of the phytoplankton. A similar result was seen in Florida Bay, where a strong wind event mixed nutrients, but also light attenuating particles and dissolved organic matter into the water column, thereby limiting any immediate response of the phytoplankton to the increased nutrient supply (Lawrence et al. 2004). However, $\sim 1$ wk following the storm, the suspended material settled, light attenuation decreased, and a phytoplankton bloom developed.

Interestingly, microzooplankton grazing rates in our study were much lower on 20 September than on the prior sampling dates, similar to the situation in the Florida Bay study (Lawrence et al. 2004). Few studies have examined how microzooplankton communities are affected by storm events in estuarine or coastal waters. Reductions in ciliate biomass have been noted in coastal systems following the passage of strong 
storms (e.g. Nielsen \& Kiørboe 1991, Zhang \& Wong 2000, Lawrence et al. 2004). Vaqué et al. (1997) observed both decreases in ciliate biomass and changes in ciliate assemblage composition in a NW Mediterranean Sea bay. However, from the few fixed samples that we have, we did not observe a reduction in ciliate abundance following passage of Tropical Strom Gordon (data not shown). It is unclear, though, whether ciliate taxonomic composition changed, as we only counted the total number of ciliates present and did not separate them into taxonomic groups. Given that phytoplankton blooms frequently occur in shallow coastal systems following storm events, further work is needed to understand the mechanisms controlling their development. Stimulation of blooms following rain events may not just be a result of increased nutrient availability, but may arise from a combination of altered nutrient dynamics and reduced grazing.

In conclusion. Our results show that in North Inlet, a shallow tidally driven salt marsh estuary, there is considerable variability in phytoplankton biomass and taxonomic composition over tidal cycles. On average, chlorophyll a decreased by 47 to $51 \%$ from low tide to high tide, and this decrease was primarily due to reductions in the abundance of pennate diatoms or flagellates, depending on sampling date. A combination of tidal input of low chlorophyll a water, and phytoplankton enhancement (resuspension, growth) and loss processes (microzooplankton grazing, oyster grazing, settling) contributed to the short-term variability. The high tidal variability in phytoplankton properties and nutrients emphasizes the need to pay strict attention to tidal stage when comparing eutrophication status between estuaries similarly influenced by tides, and in determining long-term trends in microalgal biomass and primary productivity.

Acknowledgements. We thank B. Blythe, S. Hymel, J. Keesee, J. Matkowski, A. Shurtleff, R. Tymowski, J. Williams and B. Willis for help with sampling and sample processing. We are especially grateful to M. Potthoff, who spent many hours in the field with us. Finally, we thank 2 anonymous reviewers and the associate editor, V. N. de Jonge, whose comments helped to improve this manuscript. This research was supported by a NSF Graduate Research Fellowship to M.S.W., and by NOAA grants NA90AA-D-SG672 and NA06OA0675, EPA grant R826944-01-0, and NSF grant DEB 95-09057 to A.J.L. Contribution number 1439 of the Belle Baruch Institute for Marine and Coastal Sciences.

\section{LITERATURE CITED}

Baillie PW, Welsh BL (1980) The effect of tidal resuspension on the distribution of intertidal epipelic algae in an estuary. Estuar Coast Mar Sci 10:165-180

Cognie B, Barille L, Rince E (2001) Selective feeding of the oyster Crassostrea gigas fed on a natural microphytobenthos assemblage. Estuaries 24:126-134
Cressman KA, Posey MH, Mallin MA, Leonard LA, Alphin TD (2003) Effects of oyster reefs on water quality in a tidal creek estuary. J Shellfish Res 22:753-762

Dame R (1996) Ecology of marine bivalves: an ecosystem approach. CRC Press, Boca Raton, FL

Dame RF, Zingmark RG, Haskin E (1984) Oyster reefs as processors of estuarine materials. J Exp Mar Biol Ecol 83: 239-247

Dame RF, Wolaver TG, Libes SM (1985) The summer uptake and release of nitrogen by an intertidal oyster reef. Neth J Sea Res 19:265-268

Dame RF, Bushek D, Allen D, Lewitus A, Edwards D, Koepfler E, Gregory L (2002) Ecosystem response to bivalve density reduction: management implications. Aquat Ecol 36:51-65

de Jonge VN, van Beusekom JEE (1995) Wind- and tideinduced resuspension of sediment and microphytobenthos from tidal flats in the Ems Estuary. Limnol Oceanogr 40: $766-778$

Dolan JR, Gallegos CL, Moigis A (2000) Dilution effects on microzooplankton in dilution grazing experiments. Mar Ecol Prog Ser 200:127-139

Dupuy C, Pastoureaud A, Ryckaert M, Sauriau PG, Montanie $\mathrm{H}$ (2000) Impact of the oyster Crassostrea gigas on a microbial community in Atlantic coastal ponds near La Rochelle. Aquat Microb Ecol 22:227-242

Gallegos CL (1989) Microzooplankton grazing on phytoplankton in the Rhode River, Maryland: nonlinear feeding kinetics. Mar Ecol Prog Ser 57:23-33

Gallegos CL, Jordan TE (1997) Seasonal progression of factors limiting phytoplankton pigment biomass in the Rhode River estuary, Maryland (USA). I. Control on phytoplankton growth. Mar Ecol Prog Ser 161:185-198

Hubertz ED, Cahoon LB (1999) Short-term variability of water quality parameters in two shallow estuaries of North Carolina. Estuaries 22:814-823

Jouenne F, Lefebvre S, Véron B, Lagadeuc Y (2005) Biological and physiochemical factors controlling short-term variability in phytoplankton primary production and photosynthetic parameters in a macrotidal ecosystem (eastern English Channel). Estuar Coast Shelf Sci 65:421-439

Kjerfve B, Miranda LB, Wolanski E (1991) Modeling water circulation in an estuary and intertidal salt marsh system. Neth J Sea Res 28:141-147

Kulkarni NR, White DL, Lewitus AT, Tymowski RG, Yoch DC (2005) Dimethylsulfoniopropionate in a salt marsh estuary: correlation to tidal cycle and phytoplankton assemblage composition. Mar Ecol Prog Ser 289:13-25

Landry MR, Calbet A (2004) Reality checks on microbial food web interactions in dilution experiments: responses to the comments of Dolan and McKeon. Ocean Sci Discuss 1: 65-76

Landry MR, Hassett RP (1982) Estimating the grazing impact of marine microzooplankton. Mar Biol 67:283-288

Lawrence D, Dagg MJ, Liu H, Cummings SR, Ortner PB, Kelble C (2004) Wind events and benthic-pelagic coupling in a shallow subtropical bay in Florida. Mar Ecol Prog Ser 266:1-13

Lewitus AJ, Koepfler ET, Morris JT (1998) Seasonal variation in the regulation of phytoplankton by nitrogen and grazing in a salt-marsh estuary. Limnol Oceanogr 43: 636-646

Lewitus AJ, Hayes KC, Willis BM, Burkholder JM and 5 others (2002) Low abundance of the dinoflagellates, Pfiesteria piscicida, P. shumwayae, and Cryptoperidiniopsis spp., in South Carolina tidal creeks and open estuaries. Estuaries 25:586-597 
Lewitus AJ, Kawaguchi T, DiTullio GR, Keesee JDM (2004) Iron limitation of phytoplankton in an urbanized vs. forested southeastern U.S. salt marsh estuary. J Exp Mar Biol Ecol 298:233-254

Lewitus AJ, White DL, Tymowski RG, Geesey ME, Hymel SN, Noble PA (2005) Adapting the CHEMTAX method for assessing phytoplankton taxonomic composition in southeastern US estuaries. Estuaries 28:160-172

Loret P, Pastoureaud A, Bacher C, Delesalle B (2000) Phytoplankton composition and selective feeding of the pearl oyster Pinctada margaritifera in the Takapoto lagoon (Tuamotu Archipelago, French Polynesia): in situ study using optical microscopy and HPLC pigment analysis. Mar Ecol Prog Ser 199:55-67

Lucas CH, Widdows J, Brinsley MD, Salkeld PN, Herman PMJ (2000) Benthic-pelagic exchange of microalgae at a tidal flat. 1. Pigment analysis. Mar Ecol Prog Ser 196:59-73

Lucas LV, Cloern JE (2002) Effects of tidal shallowing and deepening on phytoplankton production dynamics: a modeling study. Estuaries 25:497-507

Lucas LV, Koseff JR, Cloern JE, Monismith SG, Thompson JK (1999a) Processes governing phytoplankton blooms in estuaries. I. The local production-loss balance. Mar Ecol Prog Ser 187:1-15

Lucas LV, Koseff JR, Monismith SG, Cloern JE, Thompson JK (1999b) Processes governing phytoplankton blooms in estuaries. II. The role of horizontal transport. Mar Ecol Prog Ser 187:17-30

Mackey MD, Mackey DJ, Higgins HW, Wright SW (1996) CHEMTAX - a program for estimating class abundances from chemical markers: application to HPLC measurements of phytoplankton. Mar Ecol Prog Ser 144:265-283

Mallin MA, Esham EC, Williams KE, Nearhoof JE (1999) Tidal stage variability of fecal coliform and chlorophyll a concentrations in coastal creeks. Mar Pollut Bull 38; 414-422

Miller DC, Geider RJ, MacIntyre HL (1996) Microphytobenthos: the ecological role of the 'secret garden' of unvegetated, shallow-water marine habitats. II. Role in sediment stability and shallow-water food webs. Estuaries 19:202-212

Morris JT (2000) Effects of sea-level anomalies on estuarine processes. In: Hobbie JE (ed) Estuarine science: a synthetic approach to research and practice. Island Press, Washington, DC, p 107-127

Editorial responsibility: Victor N. de Jonge (Contributing Editor), Haren, The Netherlands
Nielsen TG, Kiørboe T (1991) Effects of a storm event on the structure of the pelagic food web with special emphasis on planktonic ciliates. J Plankton Res 13:35-51

Peierls BL, Christian RR, Paerl HW (2003) Water quality and phytoplankton as indicators of hurricane impacts on a large estuarine ecosystem. Estuaries 26:1329-1343

Pinckney JL, Zingmark RG (1991) Effects of tidal stage and sun angles on intertidal benthic microalgal productivity. Mar Ecol Prog Ser 76:81-89

Pinckney JL, Piceno Y, Lovell CR (1994) Short-term changes in the vertical distribution of benthic microalgal biomass in intertidal muddy sediments. Diatom Res 9:143-153

Porter KG, Feig Y (1980) The use of DAPI for identifying and counting aquatic microflora. Limnol Oceanogr 25:943-948

Shaffer GP, Sullivan MJ (1988) Water column productivity attributable to displaced benthic diatoms in well-mixed shallow estuaries. J Phycol 24:132-140

Sherr BF, Sherr EB, Pedros-Alio C (1989) Simultaneous measurement of rates of bacterioplankton production and protozoan bacterivory in estuarine water. Mar Ecol Prog Ser 54:209-219

Underwood GJC, Kromkamp J (1999) Primary production by phytoplankton and microphytobenthos in estuaries. Adv Ecol Res 29:93-153

Vaqué D, Blough HA, Duarte CM (1997) Dynamics of ciliate abundance, biomass and community composition in an oligotrophic coastal environment (NW Mediterranean). Aquat Microb Ecol 12:71-83

Verity PG, Blanton JO, Amft J, Barans C, Knott D, Stender B, Wenner E (1998) Influences of physical oceanographic processes on chlorophyll distributions in coastal and estuarine waters of the South Atlantic Bight. J Mar Res 56: $681-711$

Wetz MS, Lewitus AJ, Koepfler ET, Hayes KC (2002) Impact of the Eastern oyster Crassostrea virginica on microbial community structure in a salt marsh estuary. Aquat Microb Ecol 28:87-97

White DL, Porter DE, Lewitus AJ (2004) Spatial and temporal analyses of water quality and phytoplankton biomass in an urbanized versus a relatively pristine salt marsh. J Exp Mar Biol Ecol 298:255-273

Zhang W, Wang R (2000) Rapid changes in stocks of ciliate microzooplankton associated with a hurricane in the Bohai Sea (China). Aquat Microb Ecol 23:97-101

Submitted: September 22, 2005; Accepted: March 15, 2006

Proofs received from author(s): August 11, 2006 